\title{
FROM FACE-TO-FACE TO DIGITAL LEARNING; SEEN FROM EFL STUDENT'S LENSES ENROLLED IN ONLINE GROUP WORK
}

\author{
Ika Harianingsih ${ }^{1}$, Zailani Jusoh ${ }^{2}$, Ridwan Muhammad Nur ${ }^{3}$ \\ Universiti Sultan Zainal Abidin (UniSZA), Malaysia \\ Universiti Sultan Zainal Abidin (UniSZA), Malaysia \\ Universiti Sultan Zainal Abidin (UniSZA), Malaysia \\ ikaharianingsih@gmail.com \\ Received $\quad: 16 / 12 / 2021$ \\ Accepted $\quad: 19 / 12 / 2021$ \\ Publication : :20/12/2021
}

\begin{abstract}
Numerous higher education institutions around the world must shift their instructions from faceto-face (FTF) to online learning due to Corona Virus Disease in 2019 (Covid19). Furthermore, with the increase in popularity of group work in higher education, especially in the language classroom, and the pivotal changes over the last years, the group works encounter new challenges as they transition to the online world. The study aims to explore the experiences of English as a Foreign Language (EFL) students' engagement in online group works to explore the benefits and challenges in a new learning environment. The qualitative research design provided an in-depth understanding of the students' perceived value of online group work. Further, an interview was used as the main technique in collecting the data from the entire participants. Furthermore, the findings demonstrated that students had generally good attitudes about online group work; however, some students noted that language and communications concerns presented difficulty at times. Nevertheless, the findings also demonstrated that the benefits of this experience surpassed the drawbacks. Thus, the study's findings can be valuable for practitioners and curriculum designers since they highlight the benefits of group work in an online learning setting and the students' problems they may confront during these classes.
\end{abstract}

Keywords: Benefits, Challenges, Group work, online learning environment

\section{Introduction}

Group work plays an important role in the teaching and learning process since it allows students as the center of the learning process (Marks \& O'Connor, 2013). In addition, group work intends to create more active learning (Forehand et al., 2016) and an engaging environment for students (Burke, 2011). Therefore, numerous researches show that group work benefits students in several ways. For example, (Johnson \& Johnson, 2000; Li \& Lam, 2013), group work improve teamwork and social skills (Li \& Campbell, 2008; Mendo-Lázaro et al., 2018), enhance motivation and achievement (Kyndt et al., 2013; Ismail \& Allaq, 2019) and decrease students anxiety (Yassin et al., 2018). However, despite being very useful, Roskosa \& Rupniece (2016) discovered the drawbacks of implementing group work. For example, the students could deal with concentration issues, diminish work capacity, not always contribute (Chapman et al., 2006; Freeman \& Greenacre, 2011; Healy et al., 2018), free-rider (Hall \& Buzwell, 2013), and social loafer (Jassawalla et al., 2008). In addition, working alone saves more time than working in a group (Beebe \& Masterson, 2012; Soetanto \& MacDonald, 2017).

In addition, the benefits and drawbacks of group work described above are common in both FTF and online learning settings. Nevertheless, additional issues in an online learning setting need to be considered (Curtis \& Lawson, 2001; Gratton-Lavoie \& Stanley, 2009). 
Accordingly, (Curtis \& Lawson, 2001; Kim et al., 2005; Koh \& Hill, 2009; Gillett-Swan, 2017) stated that students experience more challenges when working in online group assignments than in conventional FTF classroom settings. Further researchers explain several common issues in online learning environments, such as the problem with communication, lack of sense of community and connections, and delayed response (Koh \& Hill, 2009; Maina et al., 2014; Gillett-Swan, 2017; Silalahi \& Hutauruk, 2020; Crocco \& Culasso, 2021).

Thus, scholars have emphasized examining group interaction in online learning environments where institutions utilize distance learning (Koh \& Hill, 2009; Gillett-Swan, 2017). However, in the current situations due to the covid19 pandemic, the higher education institution is required to shift from FTF learning to online learning, where instructors and students are not well equipped before entering a more digitalized learning environment (Silalahi \& Hutauruk, 2020; Warfvinge et al., 2021; Crocco \& Culasso, 2021). Consequently, both instructors and students have difficulty adapting their course delivery to an online setting specifically, utilizing group works (Warfvinge et al., 2021; Crocco \& Culasso, 2021).

Numerous literature explored students' perceptions of online group works (Hadwin et al., 2018; Ervin, 2019; Rojabi, 2020; Silalahi \& Hutauruk, 2020; Warfvinge et al., 2021; Crocco \& Culasso, 2021). Although some of the literature cited above are related to online group work, most have been in FTF settings. Research regarding group work in an online learning environment remains sparse; despite the increasing popularity of online learning. Moreover, studies exploring students' perceptions of online group work in language classrooms are not widely explored yet. In addition, there is a consideration that students' experience of group work at the early stages in higher educations will shape students' perspectives toward group work in the future (Hillyard et al., 2010). Further, Rojabi (2020) proposes that future qualitative analyses stress more on students' opinions on the benefits and challenges of taking online classes.

Therefore, a case study conducted on the first-year undergraduate students of the University of Muhammadiyah Malang enrolled in English as Specific Purpose (ESP) course aimed to explore and present an up-to-date understanding of the benefits and challenges faced by the students on a group work assignment in the online learning process during the COVID19 pandemic. Hence, there is a need to address the following research questions. First, what benefits and challenges do first-year undergraduate students encounter when undertaking group work in an online learning setting? Second, what are the implications of this research for stakeholders involved in group work in an online learning setting?

\section{Literature Review}

According to some literature, implementing group work in online learning is advantageous since it allows students to acquire critical thinking, higher-order abilities and construct knowledge and meaning (Pallof \& Pratt, 2005; Conrad \& Donaldson, 2014). In addition, learners show

flexibility and convenience as strengths of online group work (Petrides, 2002; Song et al., 2004; Koh \& Hill, 2009). Regardless of physical existence, students can still discuss with their teacher and group members by Google teams, chat rooms, and email. While students have shared their thoughts on the strengths of online group work, there have also been some concerns.

On the other hand, other literature explains that executing group work in online settings is more difficult than group work in a face-to-face setting (Garrison \& Anderson, 2011; Häkkinen, 2004; Taylor, 2005). Researchers (Chang \& Kang, 2016; Gillett-Swan, 2017) discovered several most frequent challenges in online group learning. For example, lack of sense of community and connections (Gillett-Swan, 2017) delayed response and group development stages (Chang \& Kang, 2016) and communication issues. Students felt less of the social connection in terms of personal bonding with their friends that occurs in face-to-face group discussions (Kreijns \& Kirschner, 2004; Song et al., 2004). This could lead to unfamiliarity among group members resulting in poor group dynamics (Fung, 2004). Participants in online courses said they felt disconnected from teachers and other students; in addition, a lack of connection and disconnectedness had a negative impact on their entire learning experience. 
Additionally, online group works encounter a delay in group development stages. Kim et al., (2005) stated that since group work is conducted in more digitalized settings and relies on specific software, applications, and internet connections, difficulties such as software and network is considered as a problem that might slow down interactions and limit functionality, adding to the time constraints and frustrations for facilitators and students. This problem may hamper the students' interactions in online group work (Gillett-Swan, 2017). Furthermore, delayed response was also considered a challenge in online group work. Since there was a difference in terms of time zone and the lack of face-to-face interactions, as a result, online group assignments can be particularly difficult regarding students' communication issues since delayed response and unfamiliarity among members can significantly impact group performance.

Consequently, communication difficulties are another issue mentioned in the literature (Curtis \& Lawson, 2001; Kim et al., 2005). Kim et al. (2005) stated that the most common and the toughest barriers students faced were communications. For example, some students in Vonderwell (2003) studies were concerned about possible communication issues because they did not see each other. Many of online group interactions often face asynchronous communications between students and instructors and among members, with significant delays in receiving a response (Curtis \& Lawson, 2001; McConnell, 2000; Smith, 2005). Asynchronous communication poses obstacles in terms of clear communication, collaboration, workload sharing, and relationship building. In addition, some students struggled to comprehend others' points of view or had their own misunderstood (Dyrbye et al., 2009).

Numerous prior literature related to online group work has been conducted. To begin with, Ababneh (2017) explored students' attitudes toward group work in English as Foreign Language (EFL) classrooms. The researcher conducted a survey study; the questionnaires assessing students' attitudes were distributed to 179 parties enrolled in English subjects. The respondent in this study demonstrated a moderately positive attitude towards using group work in their English classrooms. Therefore, the results may call for English teachers to shed their fear of using group work in their classes.

Additionally, Ervin (2019) conducted this intrinsic case study to comprehend better students' experiences of undergraduate students of Teacher Education in online group work settings. Data was gathered using semi-structured interviews with ten participants enrolled in an online Teacher Education course offered at the University of Learning. Integrating cooperative activities into online teacher education courses, based on the findings, lead to enhanced social, intellectual, and teaching presence within virtual learning settings, leading to improved student learning outcomes.

Furthermore, (Rojabi, 2020) conducted a study to explore students' perceptions of online group learning via Microsoft Teams. The study included twenty-eight students at Open University (Universitas Terbuka-UPBJJ Jember). The questionnaires were used to collect data on EFL students' perceptions of online learning through Microsoft Teams. Furthermore, online learning promotes student-student engagement as well as student-teacher engagement. Nonetheless, miscommunication occurs frequently in online classrooms. For example, students indicate via a questionnaire that they have communication problems with their classmates and lecturers. Further researchers suggest that future qualitative analyses could stress students' opinions, attitudes, and satisfaction with online classes and the benefits and challenges.

Next, research conducted in Indonesia by (Situmorang, 2021) aimed to determine the students' perception of using group work in English classes. The study employed a quantitative survey design and used a questionnaire as the main instrument to collect the data from the entire participant. Based on the data analysis, the findings demonstrated that students positively perceive the value of group work. Moreover, students stated that group work broadened their commitment to completing assignments.

\section{Research Method}

This study employed a qualitative case study approach. As Leavy (2017) stated, a case study is an appropriate research method used in the context of present-day phenomena in real 
life. In addition, Hamied (2017) claimed that this is the best method to explore new topics and comprehend one's beliefs. Because this study aimed to explore undergraduate students' viewpoint of group work experiences in a new learning environment, therefore qualitative case study approach was the most appropriate method used in this study. Furthermore, this study used three steps of qualitative analysis to assess data such as data reduction, data verification, and conclusion.

\section{Participant}

Since this study used purposive sampling, researchers have designed the criteria for choosing the participant. First, the participants must be first-year students. Second, students enrolled in ESP courses for at least one semester. Third, students must have experienced online learning and group work for at least one semester. Therefore, the researchers chose undergraduate students who completed the compulsory course (i.e., English as Specific Purpose), where the course was fully delivered in online learning and relied on group work. In the case study, Creswell (2016) stated that four to five subjects were enough to deliberately explore in-depth information and comprehend the subject's viewpoint of the current phenomenon. Therefore, to achieve the study objectives, four English Language Education students at the University of Muhammadiyah Malang academic year 2021/2022 were chosen as the study's respondents.

Table 1. The participants' profile

\begin{tabular}{ccccc}
\hline No. & Participants & $\begin{array}{c}\text { Sex (female } \\
\text { of male) }\end{array}$ & $\begin{array}{c}\text { Age (years } \\
\text { old) }\end{array}$ & Program \\
\hline 1 & P.1 & M & 20 & English Language Education \\
2 & P.2 & F & 19 & English Language Education \\
3 & P.3 & F & 20 & English Language Education \\
4 & P.4 & M & 19 & English Language Education \\
\hline
\end{tabular}

Based on the table above, out of four participants, two were males and females (19 to 20 years old). The participants' name was coded, the first participant as participant 1 to the fourth participant as participant 4 (henceforth P.1 to P.4). They were registered for the English Language Education Program and enrolled in an ESP course that was fully delivered in an online setting since the Covid19 pandemic in 2019. Therefore, ESP was compulsory for students to take during the semester. Additionally, each of the participants worked in different group work. Therefore, the subjects chosen in this investigation completed the research needs requirements.

\section{Data Collection}

The researcher used interview guidelines as the main instruments to collect the data along with the documentation of students when working in an online group (i.e., picture and video recorded). The interview questions used in the study were adapted from (Song et al., 2004) and (Koh \& Hill, 2005), exploring to what extent EFL students perceive the value of their enrollment in group assignments taken in online learning settings. Questions focused on exploring the benefits and challenges they experienced from the learning process. The data collection was conducted from the 10th of August 2021 to the 16th of August 2021.

\section{Data Analysis}

The present researchers used interactive model analysis to analyze the data. It is offered by (Huberman, 1994) also cited in Ibrahim (2015, p. 111). It consists of data reduction, data 
display, and verifying or making a conclusion. First, the researchers reduced data to classify and organize some data related to the focus of the research. It was carried out by making notes and making summery, then grouping them. In other words, some data which not appropriate was separated and reduced. The second step was data display. After reducing the data, researchers displayed the data in some ways. For example, narrative text and tables were administered in displaying the data. It was because this model is simpler and more suitable for this research. There were two purposes of data display. Firstly, it was to make sure the data was categorized. Secondly, it was to complete and answer the category questions made. The last was verifying or concluding. In this step, the present researchers confirmed sharpening the data and interpreting it clearly before concluding.

\section{Results and Discussions}

This current study explores undergraduate students' perception of the benefits and challenges of using group work in an online learning environment at English Language Education students at the University of Muhammadiyah Malang academic year 2021/2022.

The participants were asked to confer their reasons about the benefits and challenges of online group work through the interview. Since the entire courses they took were fully online, all participants responded based on their reasons and experiences of their learning process. In addition, there were five questions which are used in the research to collect the data. The first question was asking students about their experiences in group work in online courses. Next, the second question was asked students about the benefit of online group work. The third question was about the challenges they faced in online group work and what advice they would give to new students taking online courses and will involve in group work for the first time. The last was about suggestions to a tutor on facilitating students in group assignments in online learning. However, in the present study, the researchers focused on the benefits and challenges of online group work learning and synthesized related literature.

\section{The analysis of benefits of online group work learning environment}

The results of this study express various tendencies in the factors recognized by participants as beneficial and challenging concerning group work in an online environment. The research questions have been used to systematize the displayed data. Excerpts provided in this section were from interviews with the participants. According to the interview transcript analysis, the majority of respondents conveyed flexibility, ease of the learning process, and selfconfidence as the benefits of conducting online group work learning.

All participants perceived online group work could be done flexibly. The flexibility of online group work involves learning at anytime and anywhere as long as the available with an internet connection. For instance, P.1, one of the participants, mentioned the flexibility of doing online group work "We can do it anytime, anywhere, no need to worry about time and money to meet and come to one place to discuss." P.1 also made the following suggestions about the progress and experience in order how to manage the online group work:

Trying to divide task, group mostly consist of four members and divided the task. We should make schedule about the progress and doing task with Google meet. We seldom using WhatsApp call because it's not convenience. And we discuss our task and we discuss which one is lack from our task.

Another participant, P.2, also mentioned that in her group work discussing a task "was not difficult to make a schedule, whenever and at any times it's a lot easier" because they conducted group work in online environment "In terms of time and places online benefits us." She explained how she began to get her online group work: "I just still don't have that much of perceptions compare to offline group work. But so far Alhamdulillah all the tasks are doing so well even though we do it partly." Furthermore, she suggested that to participate in an online group work for the first-time students have to be active and have real contribution in their group work "if we are active and group work would be better and we gain more knowledge." Besides "They [group members] should have clear contributions." having better communications with 
group members was necessary to keep good performance in online group work.

The findings regarding flexibility are consistent with Petrides' (2002) study. She affirmed that participants started working in collaborative groups was easier in an online course because it did not require reorganizing everyone's schedule, unlike a traditional face-to-face course. It was also related to learning flexibility with time and choices of media used. One of the participants stated: "we often used Google meet and discussed twice in weeks and always made some communications through WhatsApp, P.4." The findings, additionally, were in line with the findings Koh \& Hill (2009) who argued that online group work learning provided students with flexibility regardless of physical existence in a specific place to attend the course. One of the participants conveyed: "it is helpful compared to offline we need to organize the time and places, P.3." For example, students through online group work learning did not require having physically meeting. It means that they do not need to meet face-to-face since they can communicate with each other by chat forums or telephone through Google Meet, WhatsApp, and email.

Additional benefits of online group work using instructional technology such as WhatsApp, zoom meeting, WebEx meeting, and others, were identified in the interviews. P.2 and P.3, two of the participants conveyed that online group work might be same as offline regarding to discussion by using media such projector "we can share our work on the screen that make us lot easier to understand materials. "It means that online group work might ease the learning process since long distance learning has been applied increasingly, due to the Covid 19. Comfort in online technology could be perceived as beneficial in online group work learning. As stated by Song et al., (2004). They affirmed that experience with the technology might be influenced the participants' perspectives of how useful the technologies were for online learning. Furthermore, Rojabi (2020) stated that students could not comprehend some difficulties in online learning since they are not accustomed to the technology. Another response regarding benefits of online group work learning, P.4, one of the participants reported that "online group work united them [group members]." Due to member groups trying to build familiarity with each other, some of the group members were from different countries and did not know each other in the initial meeting.

Other issues highlighted as benefits in this study related to how online learning could improve students' self-confidence in online group work learning. In this study, self-confidence is perceived as one of the benefits of online group work. As stated by P.2 "I do not feel anxiety because when we have the discussion. We do not see each other. So, it is freer to express anything."

\section{The analysis of challenges of online group work learning environment}

In accordance with the results of the interview transcripts, the participants identified a lack of a sense of community as the greatest challenge when working in group work, followed by communication difficulties due to internet access trouble and language difficulties stated by the students in the interview. P.2, for example, stated that "We are only a team in doing the task, not being close as a friend" because it was hard to make the connection for friends and is very difficult in online group work. Some participants who had no each other in the initial meeting, from different countries and languages, perceived that lack of a sense of community was the tough challenge faced by students in online group work learning. P.1 conveys his statement:

I can say no interactions and did not know each other in the first places, because when we conducted the online group discussions it would feel strange to each other and that make us not talk too much. In my case or in my friends' case they can overcome the connections and the familiarity is the easiest feeling for us to do the work interactions.

P.4's response affirmed that challenges of online learning were unfamiliarity between the group members "We know each other but not pretty closed, no sense of working with people in absence of physical." On the other hand, He talked about the difficulty of communication because of lack of motivation "I know one of my friends and we work online group work but we just not being focus and motivated to do the task we keep delaying and just ignore each other when we are online." 
This study's findings regarding the lack of sense of community correlate to a study conducted by Song et al. (2004). The participants felt it would be better if an instructor could facilitate students with a group arrangement (i.e., lecturer-formed group) in an online course in the initial meeting. As similarly indicated by one participant, P.2, "The lecturer expects us to be independent in doing the task and self-form the group work. Maybe it should be better if the lecturer can form us a group in every task". Practically, in order to create online group work running well, students' activities in group work should be observed by instructors. Numerous researchers have discovered that working in a group in online learning settings is more difficult than working in a conventional classroom (Garrison \& Anderson, 2011; Häkkinen, 2004; Taylor, 2005).

Additional challenges of online group work learning were difficulty in communication. Lack of communication could not be ignored when lack of internet connection occurred. The interview participants, similar to lack of internet connection, perceived language difficulty as one of challenges in online group work. P.3, for example, she reported that lack of internet connection might be one challenge that could lead to misunderstanding between students and lecturers "I think internet connection meet by all students who learn online," it was because beyond their control. She continued "... once it happens its very annoying because our communications and interactions is being disturb and we miss what the lecturer or friends explaining". It was crucial problem in online group work as stated by P.4, "that was our big problems, sometimes we miss what our friends said and did not understand it". Likewise, Kim et al., (2005) confirmed that one of the greatest obstacles among students in group work was communication. The findings demonstrated that the students' difficulty in communication is due to time zone differences and difficulty arranging scheduled meetings in online settings. In addition, Rojabi (2020) confirmed that miscommunication between students in online learning due to the poor signal often occurs in conducting an online presentation.

This study also reported that language difficulty is perceived as one challenge in online group work. P.2, one of the participants responded, "the main problem I face is the language itself. Since my English is low somehow, I found the difficulties to share my opinion". Due to her group members were different regions, she needs to increase her sense of community and develop her speaking ability. Further, she confirmed, "If I could not fluently speak English, I could show it with gestures and body language or anything it would be possible".

In addition to discussing specific benefits, challenges, and useful components, participants of the study offer several suggestions for students who will take an online course and will participate in a group assignment for the first time. For example, arranging the schedule appropriately, being active in the discussion process, and not turning off the camera to build social relationships in online group work. Additionally, P.1 reported ".... we need to take part in discussions and we need to have peers review". In addition, suggestions for instructors are followed, such as; giving more attentions to the students group work, forming students group work appropriately, one of the participants stated "...I hope lecturer much help us in facilitating and helping us". Furthermore, a participant suggested that instructors could be present in the online discussion process or periodically check student work. P.1 conveys his statement:

The instructor should give more attention to the student's team, track whether the students do the right things, and ask the students whether we face difficulties or not. If the lecturer could be part of the discussion, it would be better.

\section{Conclusion}

The current study aimed to explore the benefits and challenges experienced by the EFL students in online group work. This current study proves that students perceive the value of online group work varies but positive. For example, students consider the benefits of online group work: flexibility, ease of learning, and feeling confident. On the other hand, the difficulty of communication is presented by online environments. Furthermore, Students share their thoughts on how instructors and students should perform online group work successfully during the learning process. First, the students need to manage schedules, organize timetables before doing the task, and be present (i.e., aware and focused) in every online discussion. Second, the 
students suggest that the instructors regularly guide and check students' online group process.

Apart from the advantages and challenges of working in groups in online learning, the researchers present several practices and implications. Firstly, the challenges must be addressed to enhance learning quality and student satisfaction with online group work experiences. Learning to communicate with a diverse group of fellow students could be the key to success (Watkins \& Corry, 2007). It may be beneficial to assist students in developing strategies to handle communication difficulties in online learning settings. Secondly, there is necessary to help students build familiarity and community in virtual communities. Maintaining high levels of student motivation and encouraging a passion for learning can be difficult without a supportive student community. Thirdly, a practical instructional approach in online courses is required to improve group work. The scheme should concentrate on the technological, social, and assignment aspects that influence group development (Carabajal, K., LaPointe, D., \& Gunawardena, 2003). Finally, instructors must modify their instruction techniques to help guide students' group projects. Students may become dissatisfied if they disagree with their group members or have trouble with their group work. Therefore, developing instruction techniques to support student group work may be beneficial.

\section{References}

Ababneh, S. (2017). Attitudes of Jordanian Students Towards Using Group Work in EFL Classrooms. Advances in Language and Literary Studies, 8(1), 233. https://doi.org/10.7575/aiac.alls.v.8n.1p.233

Beebe, S. A., \& Masterson, J. T. (2012). Chapter of Communicating in small groups: principles and practices. Communicating in Small Groups, 1-31.

Burke, A. (2011). Group work: How to use groups effectively. Journal of Effective Teaching, 11(2), 87-95.

Carabajal, K., LaPointe, D., \& Gunawardena, C. N. (2003). Group development in online learning communities. Handbook of distance education, 217-234.

Chang, B., \& Kang, H. (2016). Challenges facing group work online. Distance Education, 37(1), 73-88.

Chapman, K. J., Meuter, M., Toy, D., \& Wright, L. (2006). Can’t we pick our own groups? The influence of group selection method on group dynamics and outcomes. Journal of Management Education, 30(4), 557-569.

Conrad, R. M., \& Donaldson, J. A. (2011). Engaging the online learner: Activities and resources for creative instruction (Vol. 38). John Wiley \& Sons.

Creswell, J. W., \& Poth, C. N. (2016). Qualitative inquiry and research design: Choosing among five approaches. Sage publications.

Crocco, E., \&Culasso, F. (2021). Cooperative Learning in Online Accounting Education: Challenges, Benefits, and Drawbacks. In Handbook of Research on Developing a PostPandemic Paradigm for Virtual Technologies in Higher Education (pp. 74-91). IGI Global.

Curtis, D. D., \& Lawson, M. J. (2001). Exploring collaborative online learning. Journal of Asynchronous learning networks, 5(1), 21-34.

Dyrbye, L., Cumyn, A., Day, H., \& Heflin, M. (2009). A qualitative study of physicians' experiences with online learning in a masters degree program: benefits, challenges, and proposed solutions. Medical teacher, 31(2), e40-e46.

Ervin, J. L. (2019). Undergraduate Education Students' Experiences in Online Cooperative Learning Activities: An Embedded Single-Case Study (Doctoral Dissertations, Liberty University of Education). https://digitalcommons.liberty.edu/doctoral/2218.

Forehand, J. W., Leigh, K. H., Farrell, R. G., \& Spurlock, A. Y. (2016). Social dynamics in group work. Teaching and Learning in Nursing, 11(2), 62-66.

Freeman, L., \& Greenacre, L. (2011). An examination of socially destructive behaviors in group work. Journal of Marketing Education, 33(1), 5-17.

Finegold, A. R., \& Cooke, L. (2006). Exploring the attitudes, experiences and dynamics of interaction in online groups. The Internet and Higher Education, 9(3), 201-215.

Fung, Y. Y. (2004). Collaborative online learning: Interaction patterns and limiting 
factors. Open Learning: The Journal of Open, Distance and e-Learning, 19(2), 135-149.

Garrison, D. R. (2011). E-learning in the 21st century: A framework for research and practice. Routledge.

Gillett-Swan, J. (2017). The challenges of online learning: Supporting and engaging the isolated learner. Journal of Learning Design, 10(1), 20-30.

Gratton-Lavoie, C., \& Stanley, D. (2009). Teaching and learning principles of microeconomics online: An empirical assessment. The Journal of Economic Education, 40(1), 3-25.

Hadwin, A. F., Bakhtiar, A., \& Miller, M. (2018). Challenges in online collaboration: Effects of scripting shared task perceptions. International Journal of Computer-Supported Collaborative Learning, 13(3), 301-329.

Häkkinen, P. (2004). What makes learning and understanding in virtual teams so difficult?. CyberPsychology\& behavior, 7(2), 201-206.

Hall, D., \&Buzwell, S. (2013). The problem of free-riding in group projects: Looking beyond social loafing as reason for non-contribution. Active Learning in Higher Education, 14(1), 37-49.

Hamied, F. A., \& Malik, R. S. (2017). Research methods: A guide for first-time researchers.

Healy, M., Doran, J., \& McCutcheon, M. (2018). Cooperative learning outcomes from cumulative experiences of group work: differences in student perceptions. Accounting Education, 27(3), 286-308.

Hillyard, C., Gillespie, D., \& Littig, P. (2010). University students' attitudes about learning in small groups after frequent participation. Active learning in higher education, 11(1), 9-20.

Ibrahim. (2015). Metode penelitian kualitatif. Bandung: Alfabeta.

Ismail, S. A. A., \& Al Allaq, K. (2019). The nature of cooperative learning and differentiated instruction practices in English classes. SAGE Open, 9(2), 2158244019856450.

Jassawalla, A. R., Malshe, A., \&Sashittal, H. (2008). Student perceptions of social loafing in undergraduate business classroom teams. Decision Sciences Journal of Innovative Education, 6(2), 403-426.

Johnson, S. D., Suriya, C., Yoon, S. W., Berrett, J. V., \& La Fleur, J. (2002). Team development and group processes of virtual learning teams. Computers \& Education, 39(4), 379-393.

Kim, K. J., Liu, S., \& Bonk, C. J. (2005). Online MBA students' perceptions of online learning: Benefits, challenges, and suggestions. The Internet and Higher Education, 8(4), 335-344.

Koh, M. H., \& Hill, J. R. (2009). Student perceptions of groupwork in an online course: Benefits and challenges. International Journal of E-Learning \& Distance Education/Revue internationale du e-learning et la formation à distance, 23(2), 69-92.

Kreijns, K., Kirschner, P. A., Jochems, W., \& Van Buuren, H. (2004). Determining sociability, social space, and social presence in (a) synchronous collaborative groups. CyberPsychology\& Behavior, 7(2), 155-172.

Kyndt, E., Raes, E., Lismont, B., Timmers, F., Cascallar, E., \&Dochy, F. (2013). A metaanalysis of the effects of face-to-face cooperative learning. Do recent studies falsify or verify earlier findings?. Educational research review, 10, 133-149.

Leavy, P. (2017). Research design: Quantitative, qualitative, mixed methods, arts-based, and community-based participatory research approaches. The Guildford Press.

Li, M., \& Campbell, J. (2008). Asian students' perceptions of group work and group assignments in a New Zealand tertiary institution. Intercultural Education, 19(3), 203-216.

Marks, M. B., \& O'Connor, A. H. (2013). Understanding students' attitudes about group work: What does this suggest for instructors of business?. Journal of Education for Business, 88(3), 147-158.

McConnell, D. (2014). Implementing computing supported cooperative learning. Routledge.

Mendo-Lázaro, S., León-del-Barco, B., Felipe-Castaño, E., Polo-del-Río, M. I., \& IglesiasGallego, D. (2018). Cooperative team learning and the development of social skills in higher education: the variables involved. Frontiers in Psychology, 9, 1536.

Miles, M. B., \& Huberman, A. M. (1994). Qualitative data analysis: An expanded sourcebook. sage.

Muuro, M. E., Wagacha, W. P., Kihoro, J., \&Oboko, R. (2014). Students' perceived challenges in an online collaborative learning environment: A case of higher learning institutions in 
Volume : 1 | Number 3 | December 2021 |E-ISSN : 2787-9482 |DOI: doi.org/ijeal.v1i3.1266

Nairobi, Kenya. International Review of Research in Open and Distributed Learning, 15(6), 132-161.

Petrides, L. A. (2002). Web-based technologies for distributed (or distance) learning: Creating learning-centered educational experiences in the higher education classroom. International journal of instructional media, 29(1), 69.

Rojabi, A. R. (2020). Exploring EFL Students' Perception of Online Learning via Microsoft Teams: University Level in Indonesia. English Language Teaching Educational Journal, 3(2), 163-173.

Roskosa, A., \&Rupniece, D. (2016). Advantages and drawbacks of using group work in translator training. Procedia-Social and Behavioral Sciences, 231, 244-250.

Schmitt, N., \& Schmitt, D. (2020). Vocabulary in language teaching. Cambridge university press.

Silalahi, T. F., \&Hutauruk, A. F. (2020). The Application of Cooperative Learning Model during Online Learning in the Pandemic Period. Budapest International Research and Critics Institute-Journal (BIRCI-Journal), 3(3).

Situmorang, M. A. (2021). Students' Perception of Using Group Work in English Class. JET (Journal of English Teaching), 7(1), 80-88. https://doi.org/10.33541/jet.v7i1.2302

Smith, R. O. (2005). Working with difference in online collaborative groups. Adult education quarterly, 55(3), 182-199.

Soetanto, D., \& MacDonald, M. (2017). Group work and the change of obstacles over time: The influence of learning style and group composition. Active Learning in Higher Education, 18(2), 99-113.

Song, L., Singleton, E. S., Hill, J. R., \& Koh, M. H. (2004). Improving online learning: Student perceptions of useful and challenging characteristics. The internet and higher education, 7(1), 59-70.

Taylor, V. (2005). Online group projects: Preparing the instructors to prepare the students. In Computer-supported collaborative learning in higher education (pp. 19-50). IGI Global.

Vonderwell, S. (2003). An examination of asynchronous communication experiences and perspectives of students in an online course: A case study. The Internet and higher education, 6(1), 77-90.

Warfvinge, P., Löfgreen, J., Andersson, K., Roxå, T., \&Åkerman, C. (2021). The rapid transition from campus to online teaching-how are students' perception of learning experiences affected?. European Journal of Engineering Education, 1-19.

Watkins, R., \& Corry, M. (2013). E-Learning companion: Student's guide to online success. Cengage Learning.

Weinberg, H. (2020). Online group psychotherapy: Challenges and possibilities during COVID19-A practice review. Group Dynamics: Theory, Research, and Practice, 24(3), 201.

Wilkinson, I. A., \& Fung, I. Y. (2002). Small-group composition and peer effects. International journal of educational research, 37(5), 425-447.

Yassin, A. A., Razak, N. A., \&Maasum, T. N. R. T. M. (2018). Cooperative learning: General and theoretical background. Advances in Social Sciences Research Journal, 5(8). 